\title{
Violence Against Children and Youth - the Consequences Resulting from the Civil and Church Law
}

\section{Introduction}

The protection of students at school as well as outside school, are the most important issues for teachers and those, who work with children. This article raises issues over the children's security and the results of the violation of minors' physical integrity. The subject will be discussed with respect to both lay people and clerics. The starting point will be the fragment of the pericope, connected with the child's protection by adults, where St. Joseph stands up for young Jesus: "Now, when they had departed, behold, an angel of the Lord appeared to Joseph in a dream, saying: 'Arise and take the young child and his mother, and flee into Egypt, and stay there until I tell you, for Herod will seek the young child to destroy him'. He arose and took the young child and his mother by night, and departed into Egypt." (Mt 2, 13-14).

According to this biblical text, Joseph's behaviour should be a role model not only for believers but for all adults, when we are taking into consideration the child's security. 


\section{Terminology}

We start byexplaining some terms that will allow us a better understanding of the discussed matters. We often use words: a minor and a juvenile. Who are they? The first one refers to somebody, who is not an adult (under age 18). ${ }^{1}$ The Polish Criminal Code in chapter XXV 'Offences against Sexual Liberty and Decency' states this term precisely as somebody under age 15 (victims of sexual crimes) $)^{2}$, but The Church Law determines it as somebody under the age of $18 .^{3}$ The other term mentioned: a juvenile, means a young person, who has been accused of a crime and at the time of committing a crime was under 17 years of age. ${ }^{4}$ The problems of violence will be introduced here drawing on examples which happened in schools but it is worth considering this problem within other areas of working with children and youth.

\section{Documents connected with childcare}

There are many legal acts related to the students' safeness in education law and some examples will illustrate the point. The Teacher's Charter introduces this issue as follows: A teacher is obliged to carry out the assigned tasks honestly, those connected with the basic functions of school: didactic, educational and caring, including the safety during the activities, organized by a school, as well as to form moral and civil attitudes. ${ }^{5}$ Educational law is the next document, which emphasises that teachers must have the students' health, morality and civil attitude in mind, when pursuing their tasks as teachers and they always have to respect the dignity of individuals. ${ }^{6}$ The Constitution of the Republic of Poland also says about protection of

1 Cf. Article $10 \$ 1$, Ustawa z dnia 23 kwietnia 1964 r. Kodeks cywilny - The Law of 23 April 1964 The Civil Code (Dz. U. 1964 No. 16, item 93 and its subsequent amendments).

2 Cf. Ustawa z dnia 6 czerwca 1997 r. Kodeks karny - The Penal Code of 6th of June 1997 (Dz. U. No. 88, item 553 and its subsequent amendments), Article $200 \$ 1$.

3 Cf. Benedykt XVI, Motu proprio Sacramentorum sanctitatis tutela of 21st of May $20106 \$ 1$

4 The Penal Code article $10 \$ 1$.

5 Cf. Ustawa z dnia 26 stycznia 1982 r. Karta Nauczyciela - Teacher’s Chapter (Dz. U. 2017, item 1189, 2203).

6 Cf. Article 5 Prawo Oświatowe of $14^{\text {th }}$ of December 2016 (Dz. U. 2017, item . 59, 949, 2203). 
children: "The Republic of Poland shall ensure protection of the rights of the child. Everyone shall have the right to demand of organs of public authority that defend children against violence, cruelty, exploitation and action which undermine their moral sense." In the Convention on the Rights of the Child we can read: "In all actions concerning children (...) the best interests of the child shall be a primary consideration."

\section{A short history of violence}

The problem of violence against children is relatively new when we are taking into consideration its presence in systematic studies over the years. One of the first scientists who academically gave attention to this topic, was Henry Kempe. He was the person, who in 1961, pointed to the syndrome of the beaten child. ${ }^{9}$ He also elaborated on the syndrome of sexually abused children. ${ }^{10} \mathrm{~A}$ few years later, in 1979, David Finkelhor initiated study about sexual abuse of children. ${ }^{11}$ These mentioned people gave rise to the next studies on the problem of violence toward minors.

\section{Classification of violence}

We deal with situations of different types of violence not only at schools, but also in other places: physical, psychological, cyberbullying and sexual abuse. ${ }^{12}$ 1.1. We can define physical violence as thatactivity which is not accidental and infracts the physical integrity of a child. It does not matter if

7 The Constitution of The Republic of Poland of 2 $2^{\text {nd }}$ April, 1997 (Dz. U. 1997 r. No 78, item 483, 2001. No 28, item 319, 2006 No 200, item 1471, 2009 No 114, item 946), article 72.1 .

Convention on the Rights of the Child Adopted and opened for signature, ratification and accession by General Assembly resolution 44/25 of 20 November 1989 (Dz. U. $23^{\text {rd }}$ of December 1991), article 3.1.

9 Cf. H. Kempe, N. Silverman, F. Steele, W. Droegemueller, H. Silver, The battered child syndrome, Journal of the American Medical Association, Vol. 181, 1962.

10 Cf. H. Kempe, Sexual Abuse, Another Hidden Pediatric Problem, Pediatrics, Vol. 62, 1978.

11 Cf. D. Finkelhor, Sexually Victimized Children, New York: Free Press 1981.

12 Cf. A. Kołakowska, W kręgu agresji, przemocy i brutalizacji życia. Wybrane zagadnienia, Szczytno 2004, p. 93n. 
the activity is intentional or results from negligence of the childcarer. ${ }^{13}$ Physical violence includes such behaviours as: pushing, yanking, hitting, slapping somebody's face or beating. ${ }^{14}$

1.2. Psychological violence, on the contrary, includes manipulating somebody's thought process, behaviour or physical condition in spite of her/ his lack of consent on it, expressed by means of interpersonal communication. ${ }^{15}$ The following actions fall under this group: taunting of classmates about the appearance, disclosure of shameful information and (or) family secrets, verbal harassment, disparaging, continuous comparisons to somebody else (another student in the case of schools), misrepresenting a student's surname (intentionally), intimidating students (e.g. that he/she will fail the final exams), isolation a single student from the whole group of students and supporting students' negative attitudes towards him/her. ${ }^{16}$ All the actions mentioned above, are regarded as violence although physical abuse did not take place.

1.3. Sexual abuse is such a kind of action that forces someone to behave in a certain way and (or) to have sexual contact against her/his will. This includes involving a child in a sexual activity which he/she is not able to understand, or assent to it because of his/her immaturity or because of low age. ${ }^{17}$ Sexual abuse includes: moral harassment (gestures, words, behaviour, attitudes) which have systematic and regular nature and violate the dignity or psychological integrity of students; verbal harassment (jokes, comments that have sexual character) and physical harassment (leading to a sexual activity). ${ }^{18}$ However, this aspect will be discussed further in later parts of this article.

1.4. Cyberbullying could be defined in the easiest way as violence with using information and communication technology. Here we can include: flaming - posting or sending offensive messages over the Internet;

13 Cf. A. Kołakowska, W kręgu agresji, przemocy i brutalizacji życia. Wybrane zagadnienia, Szczytno 2004, p. 44.

14 Cf. http://www.niebieskalinia.info/index.php/przemoc-w-rodzinie/8-rodzaj-przemocy (05.10.2018).

15 Cf. R. Izdebski, K. Szwajca, M. de Barbaro, W. Szaszkiewicz, Przemoc w rodzinie, maltretowanie fizyczne i wykorzystywanie seksualne dzieci i młodzieży, w: Psychiatria dzieci $i$ młodzieży, ed. I. Namysłowska, Warszawa 2012, p. 413.

16 Cf. W. Sztanter, Jak wychować ofiarę?, „Niebieska linia” 1 (6) (2000), p. 25-27.

17 Cf. M. Sajkowska, Wykorzystywanie seksualne dzieci. Ustalenia terminologiczne, skala zjawiska, oblicza problemu społecznego, „Dziecko krzywdzone” 1 (2) (2002), p. 7.

18 Cf. M. Beiser, A. Izdebska, Wykorzystanie seksualne dzieci, „Dziecko krzywdzone” 2 (39) (2012), p. 56n. 
hating - criticizing somebody in an aggressive way; trolling - starting quarrels on the Internet by posting inflammatory messages in an online community (e.g. forum); happy slapping - assaulting a stranger at random and filming the incident to post the images online. ${ }^{19}$

\section{Chosen regulations regarding the problem of violence}

The range of actions of harming students are regulated in many laws, especially in The Penal Code and The Code of Petty Offences.

\subsection{The Penal Code}

6.1.1. Defamation: "Whoever imputes to another person, a group of persons, an institution or organisational unit not having the status of a legal person, such conduct, or characteristics that may discredit them in the face of public opinion or result in a loss of confidence necessary for a given position, occupation or type to activity shall be subject to a fine, the penalty of restriction of liberty or the penalty of deprivation of liberty." 20

6.1.2. Insult: "Whoever insults another person in his presence, or though in his absence but in public, or with the intention that the insult shall reach such a person, shall be subject to a fine or the penalty of restriction of liberty. $\$ 2$. Whoever insults another person using the mass media, shall be subject to a fine, the penalty of restriction of liberty or the penalty of deprivation of liberty for up to one year."21

6.1.3. Violation of bodily integrity: "Whoever strikes a human being or in another manner breaches his personal inviolability, shall be subject to a fine, the penalty of restriction of liberty or the penalty of deprivation of liberty for up to one year."22

6.1.4. Harassment: Whoever makes a threat to another person or to his next of kin, and if the threat causes in the threatened person a justified

19 Cf. R. M. Kowalski, S.P.Limber, P.W. Agaston, Cyberprzemoc wśród dzieci i młodzie$\dot{z} y$, Kraków 2010, p. 53-59; and: M. Andrzejewska, Dzieci i młodzież w pułapce Internetu, w: M. Massalki, K. Wiatr, Zagrożenia wychowawcze XXI wieku, Warszawa 2009, p. 112-114.

20 Article $212 \$ 1$ of The Penal Code.

21 Article $216 \$ 1$ i $\$$ of The Penal Code.

22 Article $217 \$ 1$ of The Penal Code. 
fear or violates his/her privacy, shall be subject to the penalty of deprivation of liberty up to 3 years. ${ }^{23}$

6.1.5. Unlawful threats: "Whoever uses force or an illegal threat with the purpose of compelling another person to conduct himself in a specified manner, or to resist from or to submit to a certain conduct shall be subject to the penalty of deprivation of liberty for up to 3 years." ${ }^{24}$

6.1.6. Physical and mental mistreatment: "Whoever mentally or physically mistreats a person close to him, or another person being in a permanent or temporary state of dependence to the perpetrator, shall be subject to the penalty of deprivation of liberty for a term of between 3 months and 5 years. Whoever mentally or physically mistreats a minor or a person who is vulnerable because of his mental or physical condition, shall be subject to the penalty of deprivation of liberty for a term of between 6 months and 8 years."25

\subsection{The Code of Offences}

6.2.1. Malicious misrepresentation: "Who in order to annoy another person maliciously introduces it in error or otherwise maliciously is concerned, shall be punishable by restriction of liberty, a fine of up to 1500 zlotys or punishes a reprimand." 26

6.2.2. Posting offensive content in a public place: "Who in public places obscene advertisement, lettering or drawing or uses obscene words, shall be punishable by restriction of liberty, a fine of up to 1500 zlotys or punishes a reprimand." 27

All the mentioned regulations should not discourage adults from working with children and youth but should mobilize adults to treat childrenin a proper way.

\footnotetext{
23 Cf. Article 190a $\$ 1$ of The Penal Code. Aricle $191 \$ 1$ of The Penal Code. Art. $207 \$ 1, \S 1$ a of The Penal Code.

26 Ustawa z dnia 20 maja 1971 r. Kodeks wykroczeń - Act Of May 1971 The Code of Offences ( Dz.U. 1971 No 12 item 114, and its subsequent amendments) article 107.

27 The Code of Offences Article 141.
} 


\section{Disciplinary proceedings in an educational institution}

It is worth remembering that any forms of violence are a violation of children's rights and a teacher could be held responsible according to regulations included in The Teacher' $\mathrm{Charter}^{28}$. Additionally, a headmaster must not ignore any information about acts of violence in a school (caused by a teacher) and he/she is obliged to react also on the basis of article 240 of The Penal Code.

In case of receiving information about teacher's violence against pupils, a headmaster must react immediately and take action as follows:

$>$ Carry out verification activities - in order to check if the accusation is real, identify the victim and the witnesses of the situation.

$>$ Next, he/she shall inform:

$\checkmark$ pupil's parents about the situation, preliminary findings and other actions that will be taken about the problem,

$\checkmark$ the school authority and pedagogical supervisor and together with them, lay down next actions to be taken,

$\checkmark$ law enforcement authorities - if there is a suspicion of a crime committed by a teacher (e.g. beating, violation of bodily integrity, sexual abuse).

Take appropriate disciplinary action against a teacher.

A teacher, who commits violence against a pupil, should be aware of the strict consequences of his/her behaviour that are written in The Teacher's Charter. ${ }^{29}$

There are following disciplinary punishments for teachers:

$>$ reprimand with warning,

$>$ dismissal,

$>$ dismissal with the prohibition of recruitment as teachers for 3 years,

$>$ withdrawing the authorisation to pursue the occupation of being a teacher. ${ }^{30}$

Disciplinary punishments are meted out by the Disciplinary Committee that is situated in Provincial Office. Disciplinary proceedings are started by a committee at the request of the disciplinary board. These proceedings are

28 Cf. Article 75 para 1 Teacher's Chapter.(or Charter?) please change all if its a mistake.

29 Cf. Article 75 of Teacher's Chapter.

30 Article 75 para 1, Article 76 para 1 of- Teacher's Chapter. 
usually connected with a lawsuit. Additional punishment for a teacher is suspension from duty, which is necessary in the case of the violation of the rights of the child (so in each situation of violence against a child). When the issue is urgent (e.g. sexual abuse or reprehensible actions) a teacher may be suspended before the request of disciplinary proceedings is initiated in order to separate him/her immediately from the victim. ${ }^{31}$ The state of being suspended is not allowed to last more than 6 months if the case is not pending. The suspended teacher is exposed to some financial consequences. The base salary during the time of suspension may be reduced, and for somebody who is under pre-trial detention, the salary is reduced up to the half the amount, starting from the first day of the next month after the decision of the suspension has been made. At that time a teacher shall not be entitled to receive pay supplements or the salary for overtime hours. ${ }^{32}$

\section{Sexual abuse against a minor}

Sexual abuse against children is the topic which will be discussed separately. Due to the fact, that this crime may be committed by priests as well as by laity, it is worth to look at the issues from the point of civil and church law. In this regard, we focus not only on formal child protection but also about a kind of mission, and the misappropriation of it connected with consequences resulting from The Good News. For the harm done to a child, Jesus uses words of damnation: "but whoever causes one of these little ones who believe in me to stumble, it would be better for him that a huge millstone should be hung around his neck, and that he should be sunk in the depths of the sea" (Mt 18,6). The most painful cases of using violence are those committed by the people within the Church, who, in principle, should defend the most helpless. That is why violence and, what is more, sexual abuse against a child, committed by a priest, in most cases, causes separation of the victim from Jesus, mistrust towards God and Church. Pope Francis, in his homily, during Eucharist for the group of clergy sex abuse victims, on $7^{\text {th }}$ July 2014, mentioned the words written in The Good News According to Matthew: (...) What Jesus says about those who cause

\footnotetext{
31 Article 83 para 1a of Teacher's Chapter.

32 Article 84 of Teacher's Chapter.
} 
scandal applies to all of us: the millstone and the sea (compare: Mt 18, 6). ${ }^{33}$ By referring to "all of us" Pope Francis is referring to those who committed the crime, as well as those superiors who did not manage to protect children. Pope Benedict XVI referred to this issue, addressing the letter to Ireland Catholics: "All of us are suffering as a result of the sins of our confreres who betrayed a sacred trust or failed to deal justly and responsibly with allegations of abuse."34 Pope Francis spoke in a similar way during his visit in Ireland in $2018 .^{35}$ It is important to emphasize that a priest is that kind of person who should be trustworthy and uphold the safety of children. He is naturally regarded as somebody who protects the weakest so the fact of being an abuser, is particularly hurtful.

\subsection{Civil Law}

These issues are widely described in chapter XXV of The Penal Code. In case of Offences against Sexual Liberty and Decency the legislator pays attention to:

$>$ sexual intercourse with a minor under 15 or making him/her submit to another sexual act - penalty of the deprivation of liberty for a term of between 2 and 12 years, ${ }^{36}$

$>$ sharing pornographic content with a minor under 15 - penalty of the deprivation of liberty for a term up to 3 years, ${ }^{37}$

$>$ rape of a minor under 15 - penalty of the deprivation of liberty from 3 years, ${ }^{38}$

$>$ sexual abuse against mentally handicapped person - penalty of the deprivation of liberty for a term between 6 months and 8 years, ${ }^{39}$

$>$ producing, propagating and possession of pornographic material in which minors under the age of 15 participate - penalty of the deprivation of liberty for a term between 1 year and 10 years, ${ }^{40}$

\footnotetext{
33 Cf. https://m.vatican.va/cotidie/2014/documents (30.11.2018).

34 http://w2.vatican.va/content/benedict-xvi/pl/letters/2010/documents/hf_ben-xvi_ let_20100319_church-ireland.html (30.11.2018).

35 Cf. https://www.vaticannews.va/pl/papiez/news/2018-08/podroz-apostolska-irlandia-papiez-przemowienie-wladze.html (01.10.2018).

36 Article $200 \$ 1$ of The Penal Code.

37 Article $200 \$ 3-5$ of The Penal Code.

38 Article $197 \$ 3$ para 2 of The Penal Code.

39 Article 198 of The Penal Code.

40 Art. $202 \$ 3-4 c$ of The Penal Code.
} 
$>$ using IT networks to make contact with a minor under 15 to abuse him sexually - penalty of the deprivation of liberty for a term between 2 and 3 years, ${ }^{41}$

$>$ child grooming - penalty of the deprivation of liberty for a term up to 3 or 5 years. ${ }^{42}$

In cases of the discussed crimes a layman stands civil trial and a priest is subjected to canonical proceedings additionally. As was mentioned earlier, the age limit for these types of crimes in church regulations is the age of 18 .

\subsection{Canonical proceedings}

The Code of Canon Law provides for sanctions for priests who committed crimes in the sexual sphere. ${ }^{43}$ There are also some implementing rules: Motu proprio Sacramentorum sanctitatis tutela of $21^{\text {st }}$ May 2010 and The Guidelines of the Polish Episcopal Conference. According to Motu proprio Sacramentorum sanctitatis tutela of $21^{\text {st }}$ May 2010 the sexual abuse of a minor under 18 by a cleric, the settlement of it is reserved to the Congregation for the Doctrine of the Faith, among another canonical delicts. And according to the mentioned Motu proprio ${ }^{44}$ : "The more grave delicts against morals which are reserved to the Congregation for the Doctrine of the Faith are:

1. the delict against the sixth commandment of the Decalogue committed by a cleric with a minor below the age of eighteen years; in this case, a person who habitually lacks the use of a reason is to be considered equivalent to a minor;

2. the acquisition, possession, or distribution by a cleric of pornographic images of minors under the age of fourteen, for the purposes of sexual gratification, by whatever means or using whatever technology". They are Delicta graviora, reserved to the Congregation for the Doctrine of the Faith (together with those against the sanctity of the Most Holy Sacrifice and Sacrament of the Eucharist, against the sanctity of the Sacrament of Penance and against morals)".

\footnotetext{
41 Article 200a of The Penal Code.

42 Article 199 of the Penal Code.

43 Can. 1395 KPK - The Canon Law.

44 Benedykt XVI, Motu proprio Sacramentorum sanctitatis tutela of 21st of May $20106 \$ 1$.
} 
According to canon 16 Motu Proprio "Sacramentorum sanctitatis tutela" the responsibility of the Ordinary, in accordance with canon 1717 of The Canon Law, is to take the preliminary investigation in order to confirm the probability of committing a crime and in the case of receiving that confirmation, provide documentation to The Holy See. The canonical proceedings take place on the basis of The Guidelines of the Polish Episcopal Conference: "Whenever the Ordinary receives a report of a more crimes which has at least the semblance of truth, once the preliminary investigation has been completed, he is to communicate the matter to the Congregation for the Doctrine of the Faith which, unless it calls the case to itself due to particular circumstances, will direct the Ordinary how to proceed further. The acts of the investigation, the decrees of the ordinary which initiated and concluded the investigation, and everything which preceded the investigation are to be kept in the secret archive of the curia if they are not necessary for the penal process." 45

For the accused priest it results in excluding from ecclesiastical function (on the basis of article 19 Motu proprio and canon 1722 of The Canon Law) and in other cases, at least for the time of the process.

The discussion presented above, raises a question: what can one do in order not to be accused unjustly about committing the act of violence against a minor (especially sexual abuse)? The most important thing is to remember: to avoid meetings minors in isolated rooms, not to behave in a way that may be understood as favouring one minor, to avoid any physical contact which may be misunderstood with a minor, not to meet a minor in the private residence of the priest or in a residence of the minor, without the presence or the knowledge of adults, not to give presents to a minor in secret, not to compliment the physical appearance of a minor, not to abuse a minor in a verbal way (sexual jokes or comments) not to send ambiguous messages, to avoid behaviour that may treated as "a bad touch".

45 The Guidelines of Polish Episcopal Conference - Wytyczne Konferencji Episkopatu Polski, dotyczacych wstępnego dochodzenia kanonicznego w przypadku oskarżeń duchownych o czyny przeciwko szóstemu przykazaniu Dekalogu z osoba niepetnoletnia poniżej osiemnastego roku życia. Tekst, przyjęty na mocy uchwały nr 13/366/2014 Konferencji Episkopatu Polski z dnia 8 października 2014 r., został znowelizowany na mocy uchwały nr 5/376/2017 Konferencji Episkopatu Polski z dnia 6 czerwca 2017 r., p. 12. 


\section{Conclusion}

Saint John Paul II, in his homily during the Holy Mass in Łowicz on the $14^{\text {th }}$ June in 1999 said: "I I also speak to you, dear teachers and educators. You have taken on the great task of handing on knowledge and education to the children and young people entrusted to you. You are faced with a difficult and serious call. Young people need you. They look for models as points of reference. They expect answers to the many questions of life which trouble their minds and hearts, and in a special way they demand from you an example of how to live. You must be their friends, faithful companions and allies in the struggles of youth. Help them to build the foundations for their future." 46 These words are a kind of a testament for all those who take up a mission of educating of young people. ${ }^{47}$ In order to realize it well, the safety of children must be in the first place.

\section{Bibliography}

Andrzejewska M., Dzieci i młodzież w pułapce Internetu, w: M. Massalki, K. Wiatr, Zagrożenia wychowawcze XXI wieku, Warszawa 2009.

Beisert M., Izdebska A., Wykorzystanie seksualne dzieci, w: Dziecko krzywdzone. Teoria, badania i praktyka 2 (2012), s. 48-66.

Beisert M., Kazirodztwo. Rodzice w roli sprawców, Warszawa 2004.

Beisert M., Pedofilia - geneza i mechanizm zaburzenia, Gdańsk 2012.

Benedykt XVI, Motu proprio Sacramentorum sanctitatis tutela z 21 maja 2010 r. Czernkiewicz W., Pawlak-Jordan B., Wykorzystywanie seksualne dzieci, Fundacja „Dzieci Niczyje”, Warszawa 1998.

Dzieci się liczą. Raport o zagrożeniach bezpieczeństwa $i$ rozwoju dzieci $w$ Polsce, http://dzieckokrzywdzone.fdds.pl/index.php/DK/article/viewFile/584/447 (11.01.2018).

\footnotetext{
46 https://w2.vatican.va/content/john-paul-ii/en/homilies/1999/documents/hf_jpii_hom_19990614_lowicz.html (01.10.2018).

47 J. Stala, Der Mensch als Person: Die bestimmende Grundlage für Johannes Paul II. in seinem Bild von der Familie, „The Person and the Challenges” 2 (2012) nr 2, pp. 41-59; E. Osewska, J. Stala, Die katholische Schule zu Beginn des XXI. Jahrhunderts am Beispiel Polens und Englands, Warszawa 2015; J. Stala, E. Osewska, Anders erziehen in Polen. Der Erziehungs- und Bildungsbegriff im Kontext eines sich ständig verändernden Europas des XXI. Jahrhunderts, Tarnów 2009.
} 
Finkelhor D., Sexually Victimized Children. New York: Free Press 1981.

Główny Urząd Statystyczny, Oświata $i$ wychowanie $w$ roku szkolnym 2016/1016, Warszawa 2016.

http://w2.vatican.va/content/benedict-xvi/pl/letters/2010/documents/hf_ ben-xvi_let_20100319_church-ireland.html (02.10.2018).

http://www.niebieskalinia.info/index.php/przemoc-w-rodzinie/8-rodzajprzemocy (05.10.2018).

https://opoka.org.pl/biblioteka/W/WP/franciszek_i/homilie/smartaofiary_07072014.html (02.10.2018).

https://www.vaticannews.va/pl/papiez/news/2018-08/podroz-apostolskairlandia-papiez-przemowienie-wladze.html (01.10.2018).

Izdebska A., Lewandowska K., Czynniki ryzyka krzywdzenia dzieci, w: Dziecko krzywdzone. Teoria, badania i praktyka 2 (2012), p. 116-132.

Izdebski R., Szwajca K., de Barbaro M., Szaszkiewicz W., Przemoc w rodzinie, maltretowanie fizyczne i wykorzystywanie seksualne dzieci i młodzieży, w: Psychiatria dzieci i młodzieży, red. I. Namysłowska, Warszawa 2012.

Kempe H., Silverman N., Steele F., Droegemueller W., Silver H., The battered child syndrome, Journal of the American Medical Association, Vol. 181, 1962.

Kempe H., Sexual Abuse, Another Hidden Pediatric Problem, Pediatrics, Vol. 62, 1978.

Kendall P.C., Zaburzenia okresu dziecinstwa i adolescencji. Techniki terapeutyczne dla profesjonalistów i rodziców, Sopot 2016.

Kiembłowski P., Przemoc seksualna doznawana $w$ okresie dzieciństwa $i$ adolescencji - wyniki badania ankietowego młodzieży, w: Dziecko krzywdzone. Teoria, badania i praktyka 1 (2002), p. 85-112.

Kołakowska A., W kręgu agresji, przemocy i brutalizacji życia. Wybrane zagadnienia, Szczytno 2004.

Konstytucja Rzeczypospolitej Polskiej z dnia 2 kwietnia 1997 r. ( Dz. U. z 1997 r. Nr 78, poz. 483, z 2001 r. Nr 28, poz. 319, z 2006 r. Nr 200, poz. 1471, z 2009 r., Nr 114, poz. 946).

Konwencja o Prawach Dziecka przyjęta przez Zgromadzenie Ogólne Narodów Zjednoczonych dnia 20 listopada 1989 r. (Dz. U. z dnia 23 grudnia 1991 r.).

Kowalski R. M., Limber S.P., Agaston P.W., Cyberprzemoc wśród dzieci i młodzieży, Kraków 2010. 
Krawiecka M., Przemoc seksualna wobec osób z niepetnosprawnościa intelektualna, in: Interdyscyplinarne Konteksty Pedagogiki Specjalnej 2(2013), p. 57-74.

Lechowska A., Przemoc seksualna wobec dzieci z niepełnosprawnościa intelektualna, w: Dziecko krzywdzone. Teoria, badania i praktyka 1 (2008), p. 120-129.

Lew-Starowicz Z., Seksuologia sądowa, Warszawa 2014.

Marzec-Holka K., Przemoc seksualna wobec dziecka. Studium pedagogiczno-kryminologiczne, Kraków 2011.

Namysłowska I., Psychiatria dzieci i młodzieży, Warszawa 2012.

Osewska E., Stala J., Die katholische Schule zu Beginn des XXI. Jahrhunderts am Beispiel Polens und Englands, Warszawa 2015.

Piekarska A., Krzywdzenie dziecka z zaburzeniami rozwojowymi. Przeglad zagadnień teoretyczno-badawczych oraz zastosowanie taksonomii krzywdzenia dziecka, w: Dziecko krzywdzone. Teoria, badania i praktyka 2 (2007), p. 63-71.

Pieńkowska E., Izdebska A., Praca z młodymi ludźmi z obniżona sprawnościa intelektualna $w$ aspekcie ich seksualności, w: Dziecko krzywdzone. Teoria, badania i praktyka 1 (2008), p. 105-119.

Pospiszyl I., Przemoc $w$ rodzinie, Warszawa 1994.

Sajkowska M., Wykorzystywanie seksualne dzieci. Ustalenia terminologiczne, skala zjawiska, oblicza problemu społecznego, w: Dziecko krzywdzone. Teoria, badania i praktyka 1 (2002), p. 5-28.

Sajkowska M., Zjawisko krzywdzenia dzieci w świetle badań empirycznych, Fundacja „Dzieci Niczyje”, Warszawa 2001.

Salter A. C., Drapieżcy. Pedofile, gwałciciele i inni przestępcy seksualni. Kim sa, jak działaja i jak możemy chronić siebie i nasze dzieci, Poznań 2005.

Sequeira H., Holwin P., Psychological disturbace associated with sexual abuse in people with learning disabilities. Case-control study, „Britsh Journal of Psychiatry" 183 (2003), p. 451-456.

Sobsey T., Doe T., Patterns of sexual abuse and assault, „Sexuality and Disability" 9 (1991), p. 243-259.

Stala J., Osewska E., Anders erziehen in Polen. Der Erziehungs- und Bildungsbegriff im Kontext eines sich ständig verändernden Europas des XXI. Jahrhunderts, Tarnów 2009. 
Stala J., Der Mensch als Person: Die bestimmende Grundlage für Johannes Paul II. in seinem Bild von der Familie, "The Person and the Challenges” 2 (2012) nr 2, pp. 41-59.

Staręga A., Niepełnosprawni a przemoc seksualna, „Niebieska Linia” 4 (2003), p. 6-17.

Staręga A., Przemoc wobec osób niepełnosprawnych, http://www.psychologia.edu.pl/czytelnia/59-niebieska-linia/832-przemoc-wobec-osob-niepelnosprawnych.html (11.01.2018)

Ustawa z dnia 14 grudnia 2016 r. Prawo oświatowe (Dz. U. z 2017 r. poz. $59,949,2203)$.

Ustawa z dnia 20 maja 1971 r. Kodeks wykroczeń (Dz.U. $1971 \mathrm{Nr} 12$ poz. 114, z późn. zm.)art. 107. W dalszych przypisach będziemy posługiwać się skrótem Kw.

Ustawa z dnia 23 kwietnia 1964 r. Kodeks cywilny (Dz.U. 1964 Nr 16 poz. 93, z późn. zmian.).

Ustawa z dnia 26 stycznia 1982 r. Karta Nauczyciela (Dz. U. z 2017 r. poz. $1189,2203)$.

Ustawa z dnia 6 czerwca 1997 r. Kodeks karny (Dz. U. z 1997 r. Nr 88, poz. 553, z późn. zmian

Wyżyńska J., Jak chronić dzieci przed molestowaniem seksualnym. Poradnik nie tylko dla rodziców, Poznań 2007. 
